\title{
Evaluation of Warm Season Turfgrass under Different Irrigation Regimes in Arid Region
}

\author{
Abdullah Mohd Hassan ALSHEHHI'), Iqrar Ahmad KHAN ${ }^{12}$, Fahad A. ALSAID ${ }^{2}$, \\ Michael L. DEADMAN ${ }^{1)}$, Sulaiman AL-KHANJAR I3), Tanveer AHMAD ${ }^{2}$ \\ ${ }^{1)}$ Sultan Qaboos University, Faculty of Crop Sciences, Oman, Pakistan; mikedead@squ.edu.om \\ ${ }^{2)}$ University of Agriculture Institute of Horticultural Sciences, Faisalabad, Pakistan; ahmad_pshs@yahoo.com \\ ${ }^{3)}$ University of Nizwa, Oman Center for Scientific Research and Technology Development, P.O. Box 34 Al-Khoud 123, Sultanate of Oman; Pakistan
}

\begin{abstract}
Turfgrasses play a very important role in enhancing quality of life in modern urban living. Water quantity is the most important challenge worldwide in establishing and maintaining quality turf. The present study was aimed to test the performance of three warm season turfgrasses under four water levels for plantation in arid zones. Pits (48) measuring $1 \mathrm{~m}$ length $\mathrm{x} 1 \mathrm{~m}$ width $\mathrm{x} 0.6 \mathrm{~m}$ depth were planted with four replications of Common Bermuda grass (Cynodon dactylon), Tifway Bermuda grass (Cynodon dactylon $\mathrm{x}$ transvaalensis) and Seashore Paspalum grass (Paspalum vaginatum) in complete randomized design (CRD). Irrigation was done daily with 15l/plot during the first 4 weeks (establishment period) and four irrigation levels (5, 10, and 15, 20 l/lot) were maintained in the following 8 weeks (treatment period). Physical parameters (canopy temperatures, ambient temperature, leaf area, shoot production and relative water content) were measured once in two week as well as the visual quality (shoot color, shoot density and shoot uniformity) was assessed, however, chlorophyll analysis was done in the end of the study. It was found that temperature has significant effect on performance of turfgrasses. Canopy temperature was higher than ambient temperature in the three turfgrasses but it has different level in each variety. Five liter of water per day per square meter gave acceptable turf quality when ambient temperature ranged from 20 to $33^{\circ} \mathrm{C}$. Seashore paspalum performed best followed by Tifway Bermuda grass and common Bermuda grass respectively.
\end{abstract}

Keywords: aridity, turfgrass, turf quality, uniformity, water stress

\section{Introduction}

In modern urban living, turfgrasses play significant role in enhancing quality of life. They have aesthetic, economic and functional values. The turfgrass industry is considered to be a billion dollars industry which has an impact on the environment as well. A lush green turf is a dream for every green keeper. Establishing and maintaining quality turf requires ensured supply of quality irrigation water which is the most important challenge worldwide. Turfgrasses are among the most important plant groups that ae used extensively in the landscape of new cities, coastal resorts and touristic villages. Most of these communities are built in desert areas where irrigation depends primarily on relatively saline water from wells or desalination units (Sakr, 2009).

Drought is the condition resulting from dry weather, capable of damaging plant by shortening the supply of water as in the arid zone. That shortage in water supply causes water stress to plant. Turf growth and development is affected by water stress as observed in different ways and the most important effect can be seen on the cell division and growth (Mckersie and Leshem, 1994), phytohormones (Drolet et al., 1986; Smirnoff and Cumbes, 1989) stomata opening and gas exchange (Turner et al., 1978) and pho- tosynthesis (Bjorkman and Powles, 1984; Chaves, 1991; Cornic and Briantais, 1991; Lawlor, 1995). Some types of turfgrasses have the ability to avoid tissue-damage while growing in a water stress environment. This avoidance may be due to the increased root depth and root water uptake properties. On the other hand, reduction in the evapotranspiration through reduced leaf surface area, stomata closure and leaf surface properties such as epidermal hair and wax are foliage adaptations. The other mechanism by which turfgrasses overcome the water stress is through the ability of some varieties to endure low (more negative) water potentials caused by water stress. Turfgrass water requirements differ from species to species, zone to zone and from season to season. Turfgrasses mostly fulfill their water need from soil moisture, dew and rainfall. On the other hand they lose most of it by evapotranspiration, especially in the arid zone.

Oman (Latitude: $17^{\circ} 1^{\prime} 3 \mathrm{~N}$, Longitude: 544' $58 \mathrm{E}$ ) is one of the arid zone areas which have unstable and low rainfall. According to the Ministry of Regional Municipalities, Environment and Water Resources (MRME\&WR) 2005, the average annual precipitation is $100 \mathrm{~mm}$ where $80 \%$ of it evaporates, $5 \%$ goes to the sea and only $15 \%$ is held in the aquifer, whereas, $92 \%$ of the ground water is used for irrigation in agriculture. The over pumping of ground wa- 
ter has increased the problem of water availability and all that leads Oman to be one of the drought stressed areas. The problem of the water supply (drought) is further operated by high temperature (heat).

Maintaining good quality turf in an arid region is a difficult task and people are searching for turfgrass species or cultivars that will perform well in harsh desert environmental conditions. A dense turf could contribute to environmental improvement through the reduction of solar radiation intensity associated with the sunny climate of deserts. Availability of good quality irrigation water is always a constraint in the arid regions and the water desalination is an expensive alternative. In addition, due to the increased pumping of saline water from the deep wells the level of total salinity in the soils has increased (Al-Khalifah, 2004).

Salinity stress is among the major issues in agriculture and turfgrass management, and almost nowhere the plants/turfgrasses are immune to the adverse effects of salinity. Hence, to find the most tolerant turfgrass species/ cultivars to salinity stress and their uses under such conditions would probably be one of the most logical and effective solutions of the salinity stress problems (Pessarakli and Kpoec, 2009).

Bermuda grass is the main turfgrass used in Oman. It is popular grass as it is tough, require low maintenance and can be cultivated in broad environmental ranges. On the other hand Tifway hybrid Bermuda grass is also used in Oman in high maintenance program site as it has more dark green color and finer texture than the common Bermuda. Seashore Paspalum turfgrass is used by the golf courses and sport field industries all around the world. Duncan and Crorow (2000) reported that they found it long time back in costal area of Dhofar. Moreover it can be seen on some costal areas in Khasab (Musandam) and Tiwi (Sharqiya). Seashore paspalum turfgrasses have high tolerance mechanisms to overcome wide range of stresses. It has a slightly coarser texture than common Bermuda grass (Duble, 1996).

Studies are being carried out regarding plant species/ crops and their water requirements in arid regions but little has been studied to determine water use efficiency and water requirements of turfgrasses. The aim of this study was to test the performance of three warm season turfgrasses under four water levels in arid region to establish a baseline for water requirements of turfs and selection of turfgrass according to water availability.

\section{Materials and methods}

The present research was conducted at Agriculture Experiment Station of Sultan Qaboos University (SQU), located at AL-khod, Muscat, Sultanate of Oman from December 2006 till March 2007. To determine the drought tolerance in three types of turfgrasses, 48 pits measuring $1 \mathrm{~m}$ length $\mathrm{x} 1 \mathrm{~m}$ width $\mathrm{x} 0.6 \mathrm{~m}$ depth were made by remov- ing the site soil and replacing it with common agriculture soil mixed with $0.33 \mathrm{~m}^{3}$ peat moss per Plot (Fig. 1).

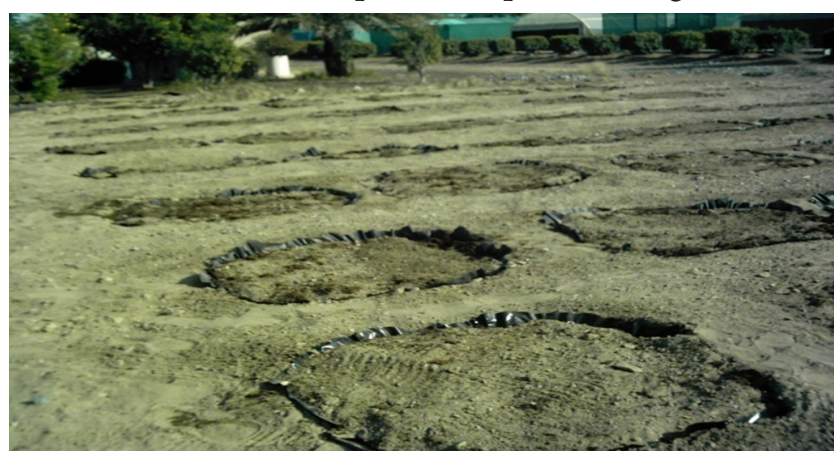

Fig. 1. Pits measuring $1 \times 1 \times 0.6 \mathrm{~m}$ filled with agri. soil and peat moss

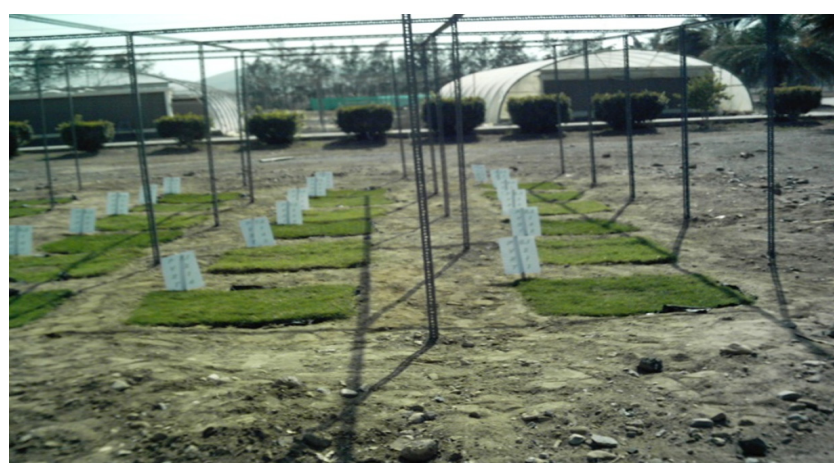

Fig. 2. Sods of turfgrasses planted in there respective pit/ditch

Before refilling, black plastic sheets with small holes at the bottom were placed in the pits to ensure that the water applied to each plot did not leak to the adjacent plot. Finally raking and leveling was done before planting. The plots were flooded with water prior to planting. Sods of same size of pit $\left(1 \mathrm{~m}^{2}\right)$ each grass was planted in respective pits (Fig. 2).

Three warm season turfgrasses were used in this experiment i.e., common Bermuda grass (Cynodon dactylon), Tifway Bermuda grass (Cynodon dactylon $\mathrm{x}$ transvaalensis) and Seashore Paspalum grass (Paspalum vaginatum). Tifway Bermuda grass and Seashore Paspalum grass were imported from United Arab Emirates, while the source of the third one was Barkah, Oman.

The experiment was laid out in complete randomized design (CRD) with three varieties, four treatments and four replications. The experiment lasted for 12 weeks in which establishment period was 4 weeks while treatment period comprised rest of the 8 weeks. All experimental pits were irrigated daily with $15 \mathrm{l} /$ pit. When sods were established during the establishment period (December 2006 to January 2007), four irrigation levels were applied to the there pits during treatment period (Tab. 1). Treatment period continued for 8 weeks (January 2007 to March 2007) during which data were collected. Irrigation was done manually using 5 and $10 \mathrm{l}$ irrigation cane at 7 am daily sticking to the water quantities. 
32

Tab. 1. Irrigation treatment levels

\begin{tabular}{ccc}
\hline \multirow{2}{*}{ Treatment } & \multicolumn{2}{c}{ Irrigation } \\
\cline { 2 - 3 } & Frequency & Quantity $\left(1 / \mathrm{m}^{2}\right)$ \\
\hline T1 & Daily & 20 \\
T2 & Daily & 15 \\
T3 & Daily & 10 \\
T4 & Daily & 5 \\
\hline
\end{tabular}

During the experiment, canopy temperature and ambient temperature were recorded on daily basis. Whereas leaf area, shoot fresh weight, shoot dry weight, relative water content, shoot color, shoot density and shoot uniformity data were collected once in every two weeks (fortnightly), i.e Week zero $\left(\mathrm{W}_{0}\right)$, Week two $\left(\mathrm{W}_{2}\right)$, Week four $\left(W_{4}\right)$, Week six $\left(W_{6}\right)$ and Week eight $\left(W_{8}\right)$ as plant were allowed to establish their shoot after every clipping as mowing was done once in two week (Carrow, 1996). Shoot color, shoot density and shoot uniformity was measured by ten researchers. At the end of the experiment chlorophyll contents were also determined. Leaf area was measured by CI-202 Portable Area Meter manufactured by CID Inc USA (Fig. 3).

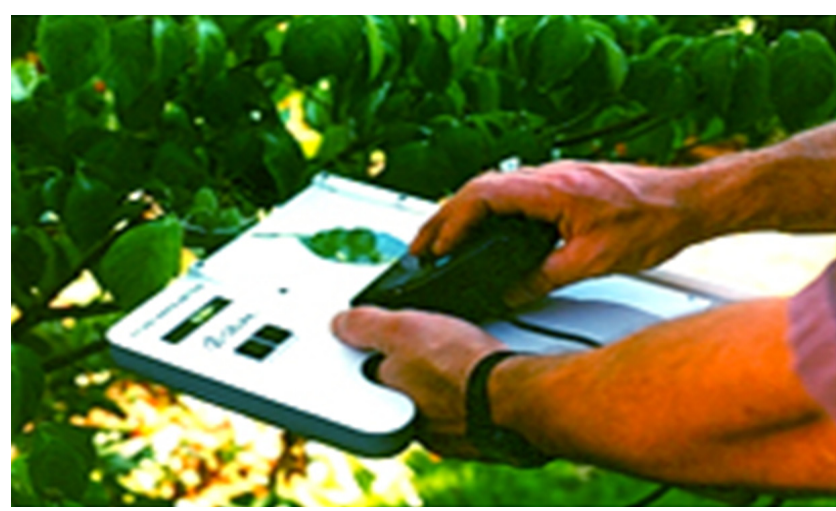

Fig. 3. CI-202 Portable area meter (CID, Inc USA)

The data were collected once in two weeks starting from week zero until week eight (Earl and Davis, 2003).

One week prior to the first treatment, every pit was clipped manually to a height of $2.5 \mathrm{~cm}$. On W $30 \mathrm{~cm}^{2}$ of each plot was clipped and weighed for shoot fresh weight (SFW). The clipped leaves were dried for 24 hours at $85^{\circ} \mathrm{C}$ and shoot dry weight (SDW) was recorded. The process was repeated fortnightly at $\mathrm{W}_{2}, \mathrm{~W}_{4}, \mathrm{~W}_{6}$ and $\mathrm{W}_{8}$ (Lee et al., 2004). In the end of experiment total shoot fresh weight (TSFW) production as well as total shoot dry weight (TSDW) were calculated (Huang et al., 1997).

Based on data collected from shoot production during the treatment period the relative water content of each treatment was derived using equation:

RWC $=$ SFW-SDW/ADWx100

Note: (RWC) Relative Water Content, (SFW) Shoot Fresh Weight, (SDW) Shoot Dry Weight.
Chlorophyll contents of the three turfgrasses were analyzed by ether extraction method.

During the treatment period, canopy temperatures (CT) of the grasses were measured daily at $11 \mathrm{am}$ (Liang and Zhang, 2000) using an infrared thermometer. The daily ambient temperature (AT), rainfall (RF), evapotranspiration $(\mathrm{ET})$ and relative humidity $(\mathrm{RH})$ readings were taken from the weather station at AES.

Three turfgrass assessment parameters were used visually in this research work including shoot color, shoot density and shoot uniformity (Waddington et al., 1992; Duble, 1996). All of the three parameters were assessed visually on the first day of $\mathrm{W}_{0}, \mathrm{~W}_{2}, \mathrm{~W}_{4}, \mathrm{~W}_{6}$ and $\mathrm{W}_{8}$ at 8 am. Shoot color was assessed on 6 scale assessment as Dark Green (DG), Green (G), Light green (LG), Yellow Green (YG), Yellow (Y) and $\operatorname{Straw}(S)$. Whereas shoot density was graded on three grades as Highly Dense (HD), Dense (D) and Less Dense (LD). On the other hand, shoot uniformity was evaluated as Uniform (U) and Not Uniform (NU).

Data obtained from the experiment were analyzed by NCSS (Number Cruncher Statistical System) 2007 version. Repeated measure analysis was applied to the physical data (SFW, SDW, RWC, LA, CT, Ca, Cb and TC). Whereas chi-square was applied for the visual quality parameters (SC, SD and SU). The model for the repeated measure was:

Equation Repeated Measures Univarite model:

$\mathrm{Xijkm}=\mu+V i+\Psi K(i)+t j+V t i j+\Psi t j K(i)+\epsilon m(i j k)$

$\mu$ : Grand mean

Vi: Effect of treatment on response variable

$\Psi K(i)$ : Subject effect nested within treatment

tj: Time effect

Vtij: Treatment $\mathrm{x}$ Time interaction

$\Psi$ tjK(i): Subject $\mathrm{x}$ Time interaction

$\epsilon$ : Error term

$\mathrm{m}$ : a dummy subscript - indicates error is nested within individual observation.

\section{Results and discussion}

Data pertaining to physical parameters showed significant differences between three varieties. Furthermore, age (in weeks) has an effect on obtained results. Tab. 2 shows the mean square of shoot fresh weight (SFW); shoot dry weight (SDW), relative water content (RWC) and leaf area (LA) as well as the significant terms. Tab. 3 indicates mean square of chlorophyll a $(\mathrm{Ca})$, chlorophyll $\mathrm{b}(\mathrm{Cb})$ and total chlorophyll (TC). Tab. 4 ANOVA table of canopy temperature (CT).

Referring to the early studies (Turgeon, 1991; Carrow, 1996; Duble, 1996) it was found that leaf area can be used as an important tool in the aspect of testing the performance of turf grasses under different irrigation treatments which gave a clear picture of the reaction of the three turf grasses used in this study to the four irrigation treatment 
Tab. 2. Mean square of SFW, SDW, RWC and LA

\begin{tabular}{cccccc}
\hline & & \multicolumn{5}{c}{ Mean Square } \\
\cline { 3 - 6 } Source term & DF & $\begin{array}{c}\text { Shoot } \\
\text { fresh } \\
\text { weight }\end{array}$ & $\begin{array}{c}\text { Shoot } \\
\text { dry } \\
\text { weight }\end{array}$ & $\begin{array}{c}\text { Relative } \\
\text { water } \\
\text { content }\end{array}$ & $\begin{array}{c}\text { Leaf } \\
\text { area }\end{array}$ \\
\hline Varieties (V) & 2 & $177.1114^{*}$ & $21.662^{*}$ & $0.2305^{*}$ & $13.8024^{*}$ \\
\hline Treatment (T) & 3 & 72.0694 & $3.7187^{*}$ & 0.0058 & 0.1383 \\
\hline $\begin{array}{c}\text { Varieties x } \\
\text { Treatment }\end{array}$ & 6 & $110.9839^{*}$ & $4.1227^{*}$ & 0.0087 & $0.0257^{*}$ \\
Week (W) & 4 & $2795.585^{*}$ & $59.946^{*}$ & $0.2674^{*}$ & $0.1711^{*}$ \\
\hline Varieties x Time & 8 & 36.7009 & 2.4959 & $0.0122^{*}$ & $0.1109^{*}$ \\
\hline Treatment x Time & 12 & 11.7910 & 0.5374 & 0.0034 & 0.0182 \\
\hline Varieties x & 24 & 19.7082 & 0.8040 & 0.0027 & 0.0251 \\
\hline Treatment x Time & 24 & & & \\
\hline *erm significant at alpha $=0.05$ & & &
\end{tabular}

Tab. 3. Mean square of $\mathrm{Ca}, \mathrm{Cb}$ and $\mathrm{Tc}$

\begin{tabular}{cccc}
\hline \multirow{3}{*}{ Source term } & \multicolumn{3}{c}{ Mean Square } \\
\cline { 2 - 4 } & $\begin{array}{c}\text { Chlorophyll } \\
\mathrm{a}\end{array}$ & $\begin{array}{c}\text { Chlorophyll } \\
\mathrm{b}\end{array}$ & $\begin{array}{c}\text { Total } \\
\text { Chlorophyll }\end{array}$ \\
\hline Varieties $(\mathrm{V})$ & $1.2939 \mathrm{E}-06^{*}$ & $1.6139 \mathrm{E}-06$ & 3.0920 \\
Treatment $(\mathrm{T})$ & $9.0769 \mathrm{E}-08$ & $1.2713 \mathrm{E}-06$ & 0.9292 \\
\hline V T & $6.4618 \mathrm{E}-07$ & $1.1451 \mathrm{E}-06$ & 2.8643 \\
\hline
\end{tabular}

* Term significant at alpha $=0.05$

Tab. 4. ANOVA table of CT

\begin{tabular}{cccccc}
\hline $\begin{array}{c}\text { Source } \\
\text { Term }\end{array}$ & DF & $\begin{array}{c}\text { Sum of } \\
\text { Squares }\end{array}$ & $\begin{array}{c}\text { Mean } \\
\text { Square }\end{array}$ & F-Ratio & $\begin{array}{c}\text { Pro P } \\
\text { Level }\end{array}$ \\
\hline A:V (Variety) & 2 & 226.8783 & 113.4392 & 32.35 & $0.000000^{*}$ \\
\hline B:T & 3 & 3.614052 & 1.204684 & 0.34 & 0.793895 \\
(Treatment) & & & & & \\
AB & 6 & 9.308559 & 1.551427 & 0.44 & 0.849398 \\
\hline C:W (Time) & 3 & 3074.229 & 1024.743 & 292.20 & $0.000000^{*}$ \\
AC & 6 & 23.46637 & 3.911061 & 1.12 & 0.356367 \\
BC & 9 & 9.598104 & 1.066456 & 0.30 & 0.972500 \\
ABC & 18 & 51.63721 & 2.868734 & 0.82 & 0.676816 \\
S & 144 & 505.0087 & 3.507005 & & \\
Total & 191 & 3903.74 & & & \\
(Adjusted) & & & & \\
Total & 192 & & & & \\
\hline
\end{tabular}

${ }^{*}$ Term significant at alpha $=0.05$

applied during this study. Leaf areas of the three varieties were found to be significantly different from each other whereas seashore produced maximum leaf area (Fig. 4). That is supported by the earlier studies by Turgeon (1991), Waddington et al. (1992) and Duble (1996). The effect of temperature on turf growth which was discussed by Beard (1973) and Duble (1996) was supported by the result of the interaction found between variety and week as the P-value (0.0083) was highly significant (Fig. 5), along with the significant change in leaf area during the period

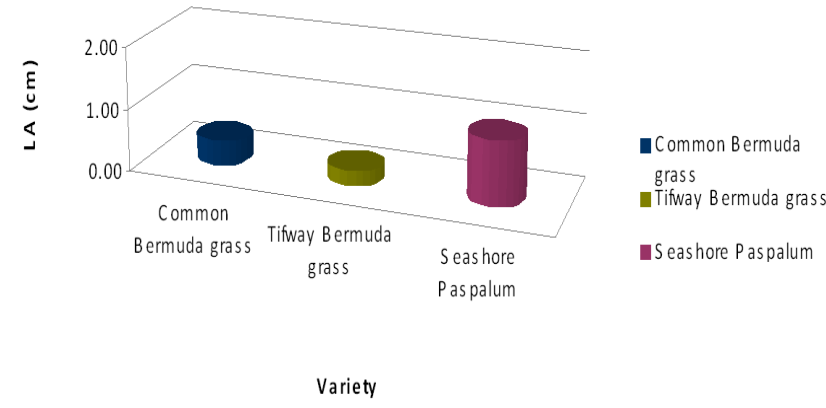

Fig. 4. Means of leaf area (L. A.) vs. variety

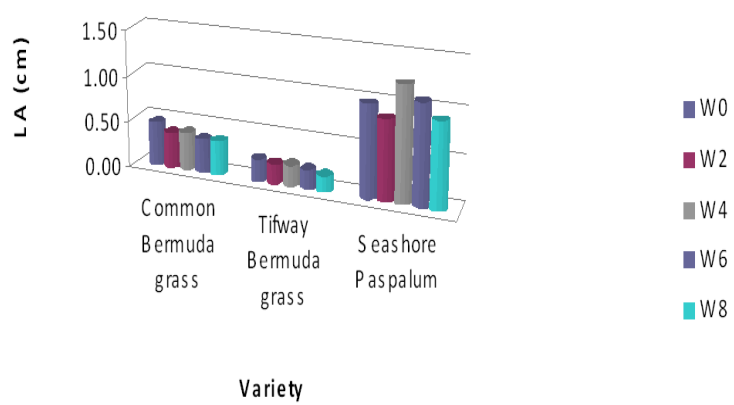

Fig. 5. Means of leaf area (LA) vs. interaction between variety and week

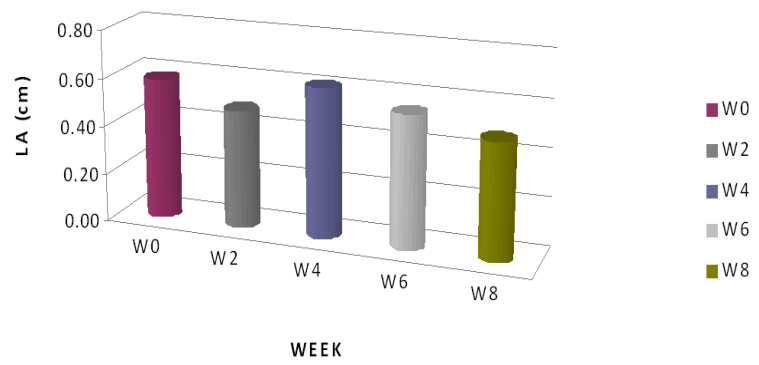

Fig. 6. Means of leaf area (LA) vs. week

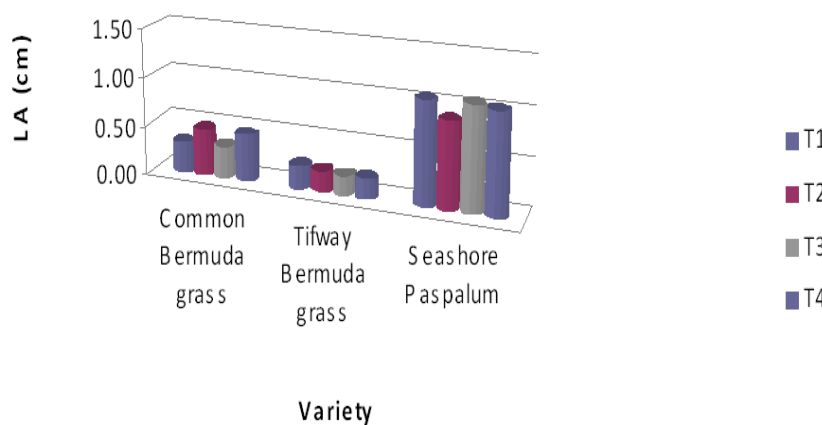

Fig. 7. Means of leaf area (LA) vs. interation between variety andtreatment

of the study ( $p$-value $=0.0031$, when alpha $=0.05)$ (Fig. 6). Common Bermuda grass and Seashore Paspalum have interaction between the treatment and leaf area (Fig. 7). Applying Tukey Kramer multiple comparison tests, the results in Tab. 5 indicates that Seashore Paspalum grass had the biggest leaf area among the three turf grass used in this 
34

Tab. 5. Tukey Kramer multiple comparison test for V and W vs. SFW, SDW, RWC, LA, CT, Ca

\begin{tabular}{|c|c|c|c|c|c|c|c|c|c|c|c|c|c|c|c|c|c|c|c|c|c|c|c|c|c|}
\hline \multirow[b]{2}{*}{ 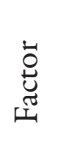 } & \multirow[b]{2}{*}{ 䒕 } & \multicolumn{4}{|c|}{ SFW } & \multicolumn{4}{|c|}{ SDW } & \multicolumn{4}{|c|}{ RWC } & \multicolumn{4}{|c|}{ LA } & \multicolumn{4}{|c|}{$\mathrm{CT}$} & \multicolumn{4}{|c|}{$\mathrm{Ca}$} \\
\hline & & 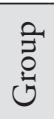 & $\stackrel{\leftrightarrows}{\Xi}$ & $\sum_{\Sigma}^{\tilde{\Xi}}$ & 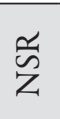 & Oे & $\stackrel{\stackrel{\Xi}{\Xi}}{\Xi}$ & $\sum^{\text {ฮँ๊ }}$ & $\begin{array}{l}\widetilde{\widetilde{n}} \\
\text { Z }\end{array}$ & $\begin{array}{l}\text { Oे } \\
\text { ठ․ }\end{array}$ & $\stackrel{\rightleftarrows}{\Xi}$ & 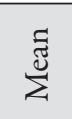 & $\frac{\widetilde{c}}{\widetilde{Z}}$ & 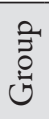 & $\stackrel{\stackrel{\Xi}{\Xi}}{\Xi}$ & 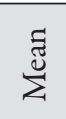 & $\begin{array}{c}\widetilde{\widetilde{Z}} \\
\text { Z }\end{array}$ & $\begin{array}{l}\text { Oे } \\
\text { O̊̆ }\end{array}$ & 芯 & $\stackrel{\Xi}{\Xi}^{\Xi}$ & $\begin{array}{l}\widetilde{\widetilde{H}} \\
\text { Z }\end{array}$ & 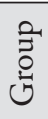 & $\stackrel{\stackrel{\Xi}{\Xi}}{\Xi}$ & $\stackrel{\Xi}{\Xi}$ & $\frac{\widetilde{A}}{\widetilde{Z}}$ \\
\hline \multirow{3}{*}{$\mathrm{V}$} & 1 & 1 & & 8.41 & $\mathrm{a}$ & 3 & & 2.03 & $a$ & 1 & \multirow{3}{*}{80} & 0.67 & $a$ & 2 & & 0.22 & $a$ & 3 & \multirow{3}{*}{64} & 40.62 & $a$ & 2 & \multirow{3}{*}{16} & 0.001 & $\mathrm{a}$ \\
\hline & 2 & 3 & 80 & 10.06 & $a b$ & 1 & 80 & 2.20 & $\mathrm{a}$ & 2 & & 0.68 & $a$ & 1 & 80 & 0.40 & $\mathrm{~b}$ & 2 & & 41.06 & $a$ & 3 & & 0.001 & $a b$ \\
\hline & 3 & 2 & & 11.38 & $\mathrm{~b}$ & 2 & & 3.00 & $\mathrm{~b}$ & 3 & & .77 & $\mathrm{~b}$ & 3 & & 1.01 & $\mathrm{c}$ & 1 & & 43.11 & $\mathrm{~b}$ & 1 & & 0.002 & $\mathrm{~b}$ \\
\hline \multirow{5}{*}{ W } & 1 & 4 & \multirow{5}{*}{48} & 3.95 & $\mathrm{a}$ & 4 & \multirow{5}{*}{48} & 1.37 & $a$ & 4 & \multirow{5}{*}{48} & .063 & $\mathrm{a}$ & 8 & & 0.48 & $a$ & 2 & \multirow{5}{*}{48} & 35.46 & $a$ & & & & \\
\hline & 2 & 2 & & 5.37 & $\mathrm{ab}$ & 2 & & 1.79 & $a b$ & 2 & & 0.64 & $\mathrm{a}$ & 2 & & .049 & $a$ & 4 & & 41.81 & $\mathrm{~b}$ & & & & \\
\hline & 3 & 0 & & 7.11 & b & 0 & & 2.07 & bc & 0 & & 0.70 & $\mathrm{~b}$ & 6 & 48 & 0.55 & $a b$ & 6 & & 42.45 & $\mathrm{~b}$ & & & & \\
\hline & 4 & 8 & & 10.42 & c & 8 & & 2.56 & c & 8 & & 0.74 & $\mathrm{c}$ & 0 & & 0.59 & $a b$ & 8 & & 46.66 & c & & & & \\
\hline & 5 & 6 & & 22.90 & d & 6 & & 4.25 & $\mathrm{~d}$ & 6 & & 0.81 & $\mathrm{~d}$ & 4 & & 0.62 & $\mathrm{~b}$ & & & $*$ & & & & & \\
\hline
\end{tabular}

${ }^{*}$ Data not taken at week zero

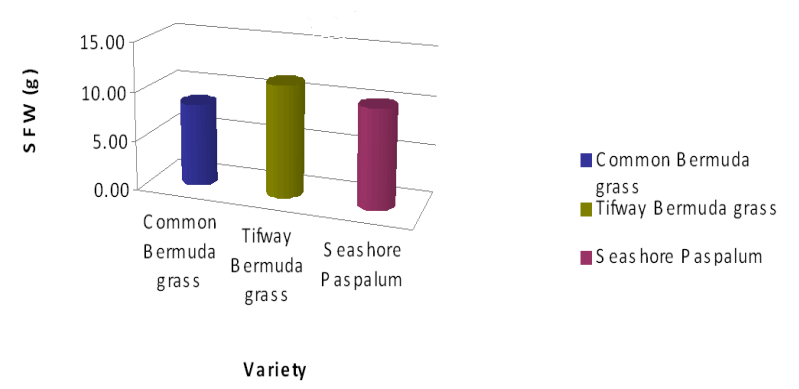

Fig. 8. Means of shoot fresh weight (SFW) vs. variety

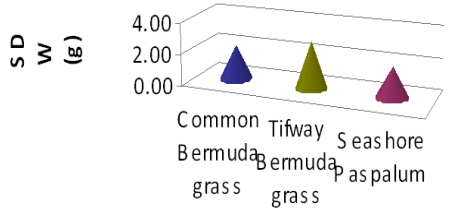

- Common Bermuda grass - Tifway Bermuda grass

S eashore Pas palum

Variety

Fig. 9. Means of shoot dry weight (SDW) vs. variety

is

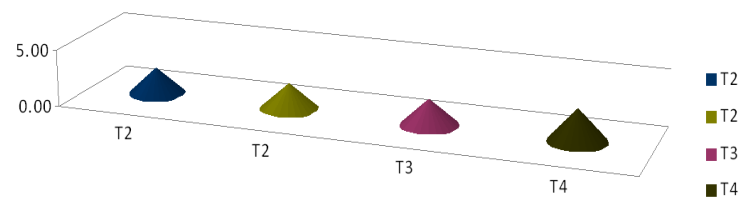

Treatment

Fig. 10. Means of shoot dry weight $v s$. water treatment

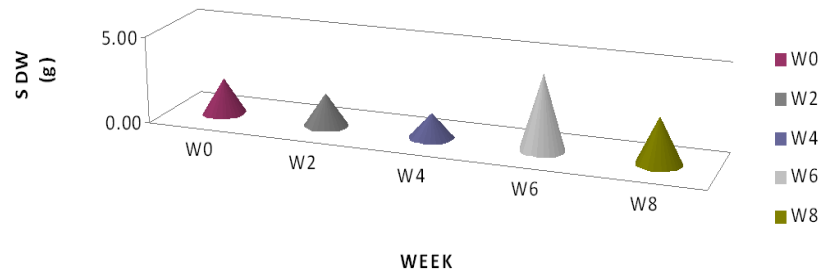

Fig. 11. Means of shoot dry weight $v$ s. week study $(1.01 \mathrm{~cm})$, followed by common Bermuda grass $(0.40$ $\mathrm{cm})$ and Tifway Bermuda grass $(0.22 \mathrm{~cm})$ respectively.

The three varieties used in this study had different shoot fresh weight production as a result of genetic difference between the three varieties used in the study as well as the respond of each variety to the irrigation level applied to them during the study. On the other hand week had highly significant effect on the production of shoot fresh weight but it was not affected significantly by water treatment levels as P-value was greater than alpha 0.05. This reflects that the three varieties did not have water stress on shoot fresh weight (Boyer, 1982; Yancey et al., 1982; Li and Chen, 2000; Pantuwan et al., 2002).

In case of shoot dry weight, irrigation levels had a significant effect beside the other two factors i.e., time and varieties, with $\mathrm{P}$-vale of 0.0442 compared to significant term alpha (0.05). Also there is significant interaction between varieties and irrigation treatment. Fig. 8 and Fig. 9 shows the mean of shoot dry weight vs. different varieties and shoot dry weight vs. week respectively. However, the shoot dry weight was linked positively to ambient temperature as we can see that the production of dry mater was increased similar to the increase in the ambient temperature in the last four weeks.

Applying regression test to the cumulative shoot production which gives the production curve presented in Fig. 10 that shows the different production levels of the three varieties under each irrigation treatment. It indicates the role of ambient temperature on the growth and clipping production of turfgrasses as there was difference between the ambient temperature in the first four weeks (average $25.85^{\circ} \mathrm{C}$ ) and the last four weeks (average $27.81^{\circ} \mathrm{C}$ ) of the study duration. Correspondingly there was slight increase in fresh shoot production in the first four weeks which increases considerably between the fourth and seventh weeks. In general shoot fresh production was ranged between $6 \mathrm{~g} / 0.03 \mathrm{~m}^{2}$ and $25 \mathrm{~g} / 0.03 \mathrm{~m}^{2}$ in the earlier four weeks in which all the curves of the three varieties under the water treatment were gathered. On contrast in the later four week of the experiment the curves spread up and the range of production was between $10 \mathrm{~g} / 0.03 \mathrm{~m}^{2}$ and 70 
Tab. 6. Shoot fresh weight cumulative production curve best - fit values

\begin{tabular}{ccccccccccccc}
\hline & V1T1 & V1T2 & V1T3 & V1T4 & V2T1 & V2T2 & V2T3 & V2T4 & V3T1 & V3T2 & V3T3 & V3T4 \\
\hline TOP & 31.52 & 38.40 & 32.83 & 73.12 & 58.80 & 57.66 & 54.24 & 62.52 & 58.48 & 49.39 & 57.56 & 46.39 \\
LOGEC50 & 5.22 & 5.20 & 5.18 & 5.46 & 5.27 & 5.19 & 5.33 & 4.91 & 5.26 & 5.35 & 5.33 & 5.30 \\
HILLSLOPE & 0.50 & 0.68 & 0.46 & 0.45 & 0.51 & 0.56 & 0.60 & 0.56 & 0.44 & 0.47 & 0.45 & 0.44 \\
EC50 & 165674 & 160098 & 151772 & 286349 & 187948 & 154771 & 214539 & 81087 & 179770 & 222286 & 212518 & 199929 \\
R $^{2}$ & 0.99 & 1.00 & 0.99 & 0.99 & 0.99 & 0.99 & 1.00 & 0.99 & 0.99 & 0.99 & 0.99 & 1.00 \\
Sy.x & 2.18 & 1.65 & 2.71 & 4.90 & 3.98 & 3.83 & 2.52 & 5.20 & 3.39 & 3.73 & 2.96 & 2.16 \\
\hline
\end{tabular}

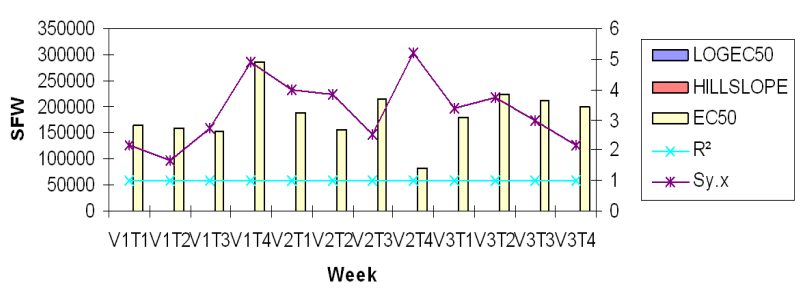

Fig. 12. Cumulative production curve for shoot fresh weight (SFW)

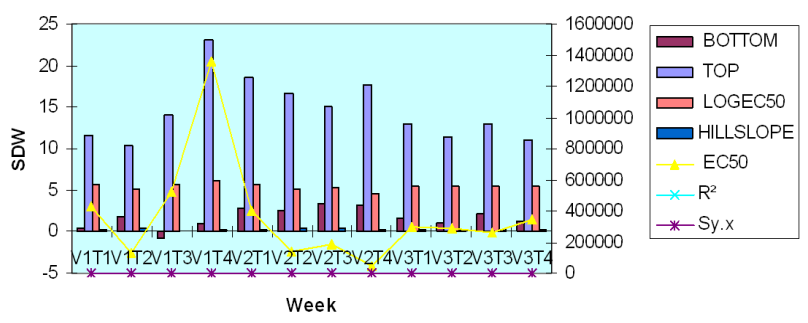

Fig. 13. Shoot dry weight (SDW) cumulative production curve best-fit values

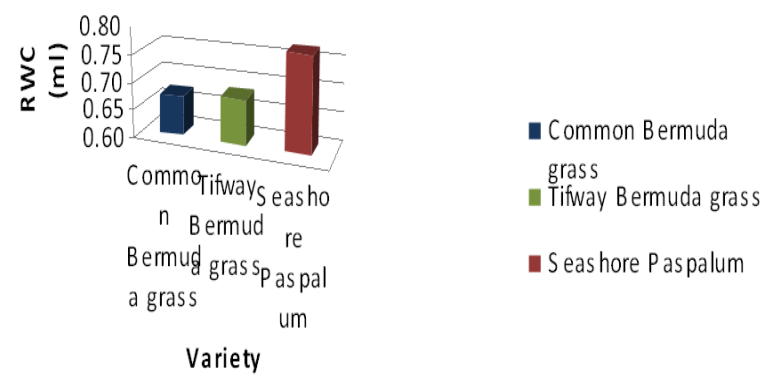

Fig. 14. Means of relative water content (RWC) vs. variety

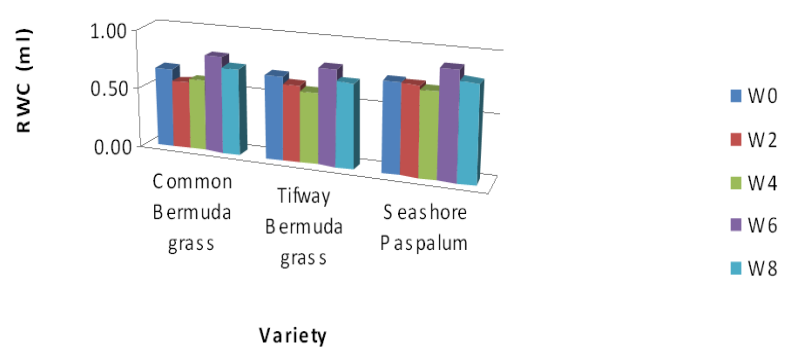

Fig. 15. Means of relative water content (RWC) vs. interaction between variety and week

$\mathrm{g} / 0.03 \mathrm{~m}^{2}$. But the higher change was between the fourth and seventh week which supports Beards (1973) that dif- ferent varieties have different conditions of production under deferent irrigation treatments (Fig. 11 and Tab. 6).

Similar to the cumulative fresh shoot production, the cumulative dry matter production curves were close to each other at the beginning of the study but became wider with the passage of time. But the dry matter production was increasing gradually since the second week of treatment until the end of the study. Fig. 12 and Tab. 4 shows the accumulative dry matter production of the different varieties under different water treatments.

Applying Tukey Kramer multiple tests for the varieties and time (Tab. 5) it can be seen that Tifway Bermuda grass produced the highest shoot fresh weight and shoot dry weight. Whereas, seashore paspalum grass had intermediate shoot fresh weight production and lowest shoot dry weight production. On the other hand common Bermuda grass had the lowest shoot fresh weight production.

Relative water contents of the three turfgrass varieties used in this study had highly significant difference and changed during the period of the experiment (Fig. 13). But there was no interaction between the factors except the interaction between the relative water content and week (Fig. 14). Fig. 15 shows means of relative water content $v s$. Interaction between variety and week. As we increase the amount of water applied there was no change in the relative water content which supported the idea that the consumption generally increases with soil water availability (Mantell, 1966; Ekern, 1966; Marsh et al., 1980; Brian et al., 1981).

Tukey Kramer multiple comparison test result showed that relative water contents of seashore paspalum were highest among the three varieties followed by the Tifway Bermuda and Common Bermuda grass. But in the case of canopy temperature the scenario was changed, the highest canopy temperature was recorded for the Common Bermuda grass followed by Tifway Bermuda and seashore paspalum (Tab. 6).

Among the different chlorophyll content calculated in this study there was significant difference between the chlorophyll a content of the different varieties. Whereas, chlorophyll $b$ and total chlorophyll contents, did not present significant differences which seems that there was no water stress on the grasses (Price and Henrdy, 1989; Malan et al., 1990; Bowler et al., 1992; Smirnoff, 1993; 1995). Tab. 4 shows the mean square of chlorophyll a, chlorophyll $\mathrm{b}$ and total chlorophyll. Comparing the literature which 
Tab. 7. Shoot dry weight cumulative production curve best-fit values

\begin{tabular}{ccccccccccccc}
\hline & V1T1 & V1T2 & V1T3 & V1T4 & V2T1 & V2T2 & V2T3 & V2T4 & V3T1 & V3T2 & V3T3 & V3T4 \\
\hline BOTTOM & 0.3657 & 1.824 & -0.888 & 1 & 2.836 & 2.583 & 3.288 & 3.113 & 1.642 & 1.138 & 2.15 & 1.349 \\
TOP & 11.55 & 10.32 & 14.09 & 23.14 & 18.58 & 16.57 & 15.01 & 17.61 & 12.94 & 11.34 & 13.05 & 11.05 \\
LOGEC50 & 5.634 & 5.117 & 5.72 & 6.137 & 5.607 & 5.149 & 5.262 & 4.636 & 5.47 & 5.464 & 5.423 & 5.532 \\
\hline HILLSLOPE & 0.1934 & 0.4189 & 0.1375 & 0.1973 & 0.2412 & 0.3255 & 0.3516 & 0.2853 & 0.2448 & 0.2573 & 0.261 & 0.2706 \\
EC50 & 430712 & 130999 & 524697 & $1.37 \mathrm{E}+06$ & 404377 & 140971 & 182721 & 43234 & 294901 & 290854 & 265052 & 340400 \\
R $^{2}$ & 0.9902 & 0.9921 & 0.9913 & 0.989 & 0.9881 & 0.9902 & 0.9931 & 0.9874 & 0.9937 & 0.9907 & 0.9953 & 0.9948 \\
Sy.x & 0.6064 & 0.6253 & 0.6033 & 1.228 & 1.076 & 1.045 & 0.7494 & 1.188 & 0.569 & 0.6464 & 0.4952 & 0.4672 \\
\hline
\end{tabular}

Tab. 8. Chi Square test for visual quality parameter

\begin{tabular}{ccccccccccccccc}
\hline Factor & \multicolumn{1}{c}{ SC } & \multicolumn{1}{c}{ SD } & \multicolumn{3}{c}{ SU } \\
\hline & Chi-Square & Df & P & Significance & Chi-Square & Df & P & Significance & Chi-Square & Df & P & Significance \\
W & 28.9 & 16 & 0.0245 & $*$ & 39.49 & 8 & 0.0001 & ${ }^{* * *}$ & 5.878 & 4 & 0.2085 & $\mathrm{~ns}$ \\
$\mathrm{~V}$ & 182.7 & 8 & 0.0001 & ${ }^{* * *}$ & 95.45 & 4 & 0.0001 & ${ }^{* * *}$ & 113.7 & 2 & 0.0001 & $* * *$ \\
$\mathrm{~T}$ & 19.19 & 12 & 0.0839 & $\mathrm{~ns}$ & 13.9 & 6 & 0.03 & ${ }^{*}$ & 6.11 & 3 & 0.11 & $\mathrm{~ns}$ \\
\hline
\end{tabular}

${ }^{* * * *}$, significant at 0.05 and 0.001 probability levels respectively

$\mathrm{ns}$, not significant

describes the three varieties used in this study we can see that there is difference in the sharpness of the shoot color among them which is supported by the obtained result of Chlorophyll a.

From Tukey Kramer multiple comparison test (Tab. 5) Chlorophyll a contents were higher in seashore paspalum grass followed by Tifway Bermuda grass while the lower Chlorophyll a contents were observed in Common Bermuda grass.

During the study the ambient temperature ranged between $21.70^{\circ} \mathrm{C}$ and $33.70^{\circ} \mathrm{C}$ which fall in the optimum ranges of warm season turf grasses $\left(27-35^{\circ} \mathrm{C}\right.$ ) (Youngner et al., 1981; Beard, 1973). The maximum day temperature $\left(33.70^{\circ} \mathrm{C}\right)$ was in week 8 and the minimum day temperature $\left(21.70^{\circ} \mathrm{C}\right)$ was in week 2 . Although there was gradual increase in the minimum day temperature during the study time, there was an increase of $13^{\circ} \mathrm{C}$ in the maximum day temperature between week 8 and the earlier weeks in which the maximum day temperature remains consistent. On average the ambient temperature during the experiment was $26.5^{\circ} \mathrm{C}$ in the first four weeks and increased by $1^{\circ} \mathrm{C}$ in the other four weeks.

The results obtained from this study supported the facts that canopy temperature was different between different grass species and it related positively to ambient temperature and was $2^{\circ} \mathrm{C}$ lower than ambient temperature (Duff and Beard, 1966). Although there was no interaction between the variety, time and water treatment but varieties had high difference in their canopy temperature and it varied considerably as time changed in which ambient temperature also changed (Tab. 6). Supporting the previous indication of the early discussed parameter that illustrated that there is no water stress on the three varieties because of the different irrigation treatments used, canopy temperature did not affect significantly by the treatment levels which indicate that all grasses do not have water stress under the four treatment levels which was stated by early studies.

Chi square test is applied on data of visual quality parameters. Shoot color (SC), Shoot Density (SD) and Shoot Uniformity. Tab. 8 shows a summary of chi square test result of visual quality parameter in which varieties have highly significant difference in all of the three parameters whereas water treatment does not have any significant effect except on shoot density. However time has highly significant effect in the case of shoot density and shoots color but no significant effect on shoot uniformity.

\section{Conclusions}

Seashore paspalum has a coarser texture among the three varieties whereas Tifway is the finest. Also Tifway had higher shoot production compared to the other two. Paspalum leaf was 2.5 times larger than the Common Bermuda grass leaf, but they had similar shoot fresh and dry weight production. Common Bermuda and Tifway Bermuda have lower relative water content. Temperature has significant effect on performance of turfgrasses. Canopy temperature was higher than ambient temperature in the three turfgrasses but it had different level in each variety. In general, Paspalum canopy temperature was two degree higher than the others. Seashore paspalum, Tifway and Common Bermuda grasses can be managed well in arid zones. Five liter of water per day per square meter gave acceptable turf quality when ambient temperature ranged from 20 to $33^{\circ} \mathrm{C}$.

The performance of the three varieties and their response under the different treatment levels was acceptable. Seashore paspalum performed best followed by Tifway Bermuda grass and common Bermuda grass respectively. Longer experiment duration with more factors and more sophisticated testing instruments will give more reliable 
data. Also, testing the performance of these turfgrasses under different stress types and levels will clear the picture of which variety can be used all over the country. Including the wild variety of turfgrasses which are found in different places could be a very useful tool to find highly tolerant turfgrasses for the arid regions.

\section{References}

Al-Khalifah, S. N. (2004). Response of some turfgrasses to salinity and environmental conditions of Saudi Arabia. Emirat Journal of Agricultural Scinces 16(2):09-17.

Beard, J. B. (1973). Turfgrass science and culture. Prentice-Hall, Englewood Cliffs, New Jersy. USA.

Bjorkman, O. and S. B. Powles (1984). Inhibition of photosynthetic reactions under water stress: interaction with light level. Planta 161:490-504.

Bowler, C., M. V. Montagu and D. Inze (1992). Superoxide dismutase and stress tolerance. Annual Review of Plant Physiology and Molecular Biology 43:83-116.

Boyer, J. S. (1982). Plant productivity and environment. Science 218:443-448.

Brian, L. B., I. Bravdo and E. R. Bushkin-Harav (1981). Water consumption and growth rate of eleven turfgrasses as affected by mowing height, irrigation frequency and soil moisture. Agron. J. 73:85-95.

Carrow, R. N. (1996). Drought resistance aspects of turfgrasses in the southeast: Root - shoot responses. Crop Sci 36:687694.

Chaves, M. M. (1991). Effect of water deficits on carbon assimilation. J. Exp. Bot. 42:1-16.

Cornic, G. and J. M. Briantais (1991). Partitioning of photosynthetic electron flow between $\mathrm{CO}_{2}$ and $\mathrm{O}_{2}$ reduction in a $\mathrm{C}_{3}$ leaf (Phaseolus vulgaris) at different $\mathrm{CO}_{2}$ concentrations and during drought stress. Planta 183:178184.

Drolet, G., E. B. Dumdroff, R. I. Legge and J. E. Thompson (1986). Radical scavenging properties of polyamines. Phytochemistry 25:367-371.

Duble, R . (1996). Turfgrasses, Texas A and M University Paris College Station.

Duff, D. T. and J. B. Beard (1966). Effects of air movement and syringing on the microclimate of Bentgrass. Turfgrass Agron. J. 58:495-497.

Duncan, R. R. and R. N. Carrow (2000). Seashore Paspalum the environmental turfgrass. Ann Arbor Press, Chelsea, Michigan.

Earl, H. J. and R. F. Davis (2003). Effect of drought stress on leaf and whole canopy radiation use efficiency and yield of maize. Agron. J. 95:688-696.

Ekern, P. C. (1966). Evapotranspiration by Bermuda grass sod, Cynodon dactylon L. Pers in Hawaii. Agron. J. 58:387-390.

Huang, B., R. R. Duncan and R. N. Carrow (1997). Drought- resistance mechanisms of seven-warm season turfgrasses under Surface Soil Drying: I. Shoot aspects. Crop Sci. 37:1863-1869.

Lawlor, D. W. (1995). The effects of water deficits on photosynthesis. In: N. Smirnoff (eds.) Environment and plant metabolism: flexibility and acclimation. BIOS Scientific Publishers Limited. Oxford, UK.

Lee, G. R. Carrow and R. Duncan (2004). Growth and water relation responses to salinity stress in halophytic seashore paspalum ecotypes. Sci. Horti. 104:221-236.

Li, Z. Y. and S. Y. Chen (2000). Differential accumulation of the sadenosylmethionine decarboxylase transcript in rice seedlings in response to salt and drought stress. Theoretical and Applied Genetics 100:782-788.

Liang, Y. L. and C. G. Zhang (2000). The relationship between discrepancy of canopy and air temperature and crop water deficiency. Eco-Agric Research. 8(1):24-26.

Malan, C., M. M. Greyling and J. Gressel (1990). Correlation between $\mathrm{Cu} / \mathrm{Zn}$ superoxide dismutase and glutathione reductase, and environmental and xenobiotic stress tolerance in maize inbreds. Plant Science 69:157-166.

Mantell, A. (1966). Effect of irrigation frequency and nitrogen fertilization on growth and water use of Kikuya grass lawn (Pennisetum daldestinum Hockst.). Agron. J. 58:559-561.

Marsh, A. W., R. A. Strokman, S. Spaulding, V. Youngner and V. G. Gibeault (1980). Turfgrass irrigation research, University of California.

Mckersie, B. D. and Y. Y. Leshem (1994). Stress and stress coping in cultivated plants. Klumer Academic Publishers, Netherlands.

Pantuwan, G., S. Fukai, M. Cooper, S. Rajatasereekul and J. C. O’Toole (2002). Yield response of rice (Oryza sativa L.) genotypes to drought under rainfed lowland. Plant factors contributing to drought resistance. Field Crop Research 73:181-200.

Pessarakli, M. and D. M. Kopec (2009). Screening various ryegrass cultivars for salt stress tolerance. Journal of Food, Agriculture and Environment 7 (3,4):739-743.

Price, A. H. and G. A. F. Henry (1989). Stress and the role of activated oxygen scavengers and protective enzymes on plants subjected to drought. Biochemistry Society Translation 17:493-496.

Sakr, A. R. W. (2009). Response of Paspalum turfgrass grown in sandy soil to Trinexapac-Ethyle and irrigation water salinity, Journal of Horticultural Sciences and Ornamental Plants $1(2): 15-26$.

Smirnoff, N. (1993). The role of active oxygen in the response of plants to water deficit and desiccation. New Phytologist 125:27-58.

Smirnoff, N. (1995). Antioxidant systems and plant response to the environment. In: N. Smirnoff (Eds.) Environemnt and plant metabolism:flexibility and acclimation. BIOS Scientific Publishers. Oxfored, UK. 
38

Smirnoff, N. and G. J. Cumbes (1989). Hydroxyl radical scavenging activity of compatible solutes. Photochemistry 28:1057-1060.

Turgeon, A. (1991). Turfgrass Management, Prentice- Hall, Inc. Engllewood Cliffs, New Jersey 07632.

Turner, N. C., J. E. Begg, H. M. Rawson, S. D. English and A. B. Hearn (1978). Agronomic and physiological responses of soybean and sorghum crops to water deficits. Components of leaf water potential, leaf conductance, 14CO2 photosynthesis, and adaptation to water deficit. Australian Journal Plant Physiology 5:179-194.
Waddington, D., R. Carrow and R. Shearman (1992). Turfgrass. Madison. Wisconsin USA.

Yancey, P. H., M. E. Clark, S. C. Hand, R. D. Bowlus and G. N. Somero (1982). Living with water stress: evolution of osmolyte system. Science 217:1214-1222.

Youngner, V. B., A. W. Marsh, R. A. Strohman, V. A. Gibeault and S. Spalding (1981). Water use and quality of warmseason and coolrelations season turfgrasses. Turfgrass Society and University of Guelph, ON, Canada pp.257-259. 